\title{
THE INFLUENCE OF OVERLOAD STRESSES \\ ON DURABILITY OF CERAMIC ELEMENTS IN HIP JOINT ENDOPROSTHESES
}

\author{
Michat Sobociński \\ Institute of Mechanical Technology, Czestochowa University of Technology \\ Czestochowa, Poland \\ sobocinski@iop.pcz.pl
}

\begin{abstract}
The paper raises the problems connected with the durability of ceramic elements used in technology. It presents mathematic - statistic methods defining the influence of stress on ceramic elements durability. The paper also contains the results of numerical analysis carried out by the Finite Elements Method in the ADINA system, considering a ceramic elements. The above analysis is confirmed and proved by the experimental tests on a "head - cup" set, carried out on the hip-joint simulator.
\end{abstract}

Keywords: durability, stress, numerical analysis

\section{Durability of ceramic elements}

The most common solution offered by endoprostheses producers as far as joints construction is concerned, is the application of replaceable cup in metal casing. That solution decreases the range of surgery when the friction elements of endoprosthesis are worn. The cups in such systems usually consist of a metal casing made of titanium alloy Ti6Al4V and an appropriate insert. The replaceable internal element can be made of UHMWPE, bio-ceramic or double-layer materials [1].

All the ceramic materials used in endoprostheses elements are subjected to high loads. It is important that due to the specific shape of tribologically cooperating surfaces, the point of contact is formed.

All the data concerning the durability of ceramic materials can be gained i.e. by mathematic - statistic methods. In this case, the tests are conducted on chosen samples with the same kind and size of defects as the analysed parts. Based on the obtained measurements the conclusions concerning the parameters of whole group of parts, can be drawn. It is mandatory to perform a strength analysis which can lead to assigning the most dangerous fracture by using the pattern:

$$
a=\frac{K_{I_{C}}^{2}}{\sigma^{2} Y^{2}}
$$


where:

$K_{I_{c}}$ - critical coefficient of stress intensity,

$\sigma$ - strength,

$Y$ - shape coefficient,

$a$ - apparent length of fracture.

The value of shape coefficient $Y$ is usually approximate [2].

Having the sub-critical increase of fractures it is possible to define the durability of mechanically loaded ceramic elements. Durability $t$ of the ceramic element constantly subjected to load can be calculated as follows:

$$
d t=\frac{1}{A(\sigma \sqrt{a} Y)^{n}} d a,
$$

and after integration:

$$
t=\frac{2}{(n-2) A \sigma^{n} Y^{n}}\left(\frac{1}{\sqrt{a_{a}^{n-2}}}-\frac{1}{\sqrt{a_{c}^{n-2}}}\right)
$$

where:

$a_{a}$ - length of the most dangerous fracture before subjecting to load,

$a_{c}$ - critical length of fracture.

Using non-destructive methods, it is currently possible to primarily assign length of the most dangerous fracture. When ceramic $\mathrm{Al}_{2} \mathrm{O}_{3}$ is used in endoprosthesis, the constant values $A$ and $n$ are as follows:

$$
\begin{gathered}
\lg A=-40 \\
n=60
\end{gathered}
$$

If for the randomly chosen sample the destructive stress distribution is assigned and recalculated by:

$$
\frac{\sigma_{b(3-p)}}{\sigma_{b(4-p)}}=\left(\frac{m+2}{2}\right)^{\frac{1}{m}}
$$

where for ceramic $\mathrm{Al}_{2} \mathrm{O}_{3}$ :

$m=7$

$\sigma_{0}=330 \mathrm{MPa}$.

It is possible to define the durability by the equation (3). When the above calculations are made for various stress values $\sigma$, the SPT (Strength - Probability - Time) graph can be presented. Based on that - we can settle the amount of samples that have been damaged before the durability time $t$ expires.

When the minimum durability value is required, the method of proof testing can be used. 


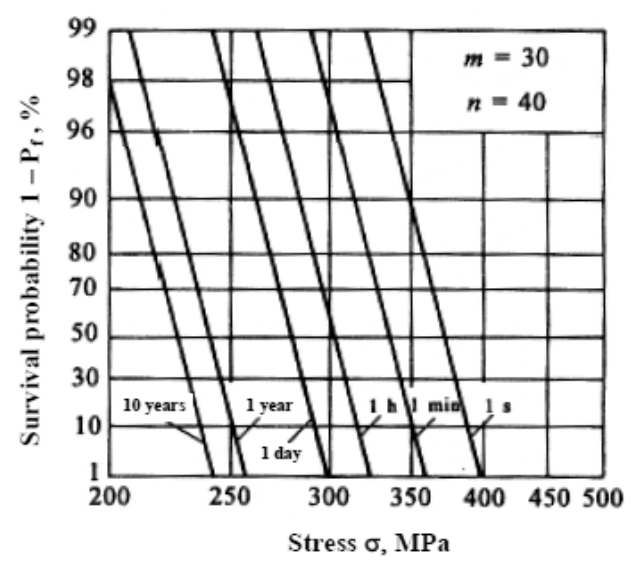

Fig. 1. Graph SPT, dependence of survival probability on stress in various time of load [3]

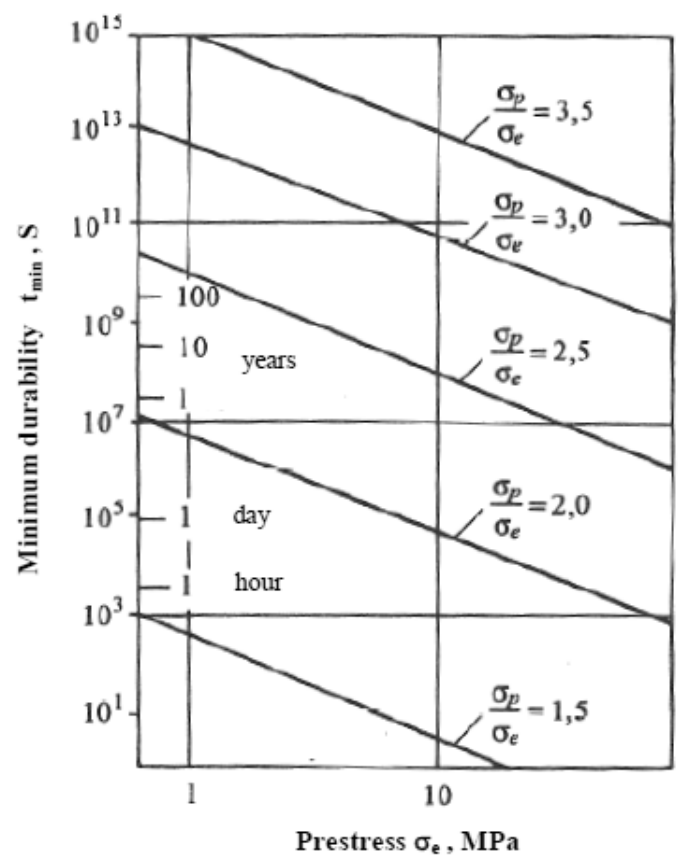

Fig. 2. Graph Proof - test, dependence of minimal durability $\mathrm{t}_{\min }$ on functional stress $s_{e}$ for various overloads relations $\sigma_{p} / \sigma_{e}[3]$

When using the above method, the tested samples must be initially subjected to stress $\sigma_{p}$, which is higher than stress $\sigma_{e}$, which occurs when the samples are in use. When subjected to the initial load, the samples are not led to damage due to: 


$$
K_{I c}>\sigma_{p} \sqrt{a_{p}} Y \text { lub } a_{p}<\left(K_{I c} / \sigma_{p} Y\right)^{2} .
$$

assigning that limit defines minimal durability $t_{\min }$ :

$$
t_{\text {min }} \geq \frac{2}{(n-2) A \sigma_{e}^{2} Y^{2} K_{I c}^{n-2}}\left(\frac{\sigma_{p}}{\sigma_{e}}\right)^{n-2}
$$

Some ceramic parts require initial tests. That eliminates the parts with significant internal defects from the lot. All the remaining ones are considered as of higher durability than $\sigma_{p}$, assigned in initial trial [3].

\section{Numerical analysis of overload stress and strain in "head - cup" set of hip joint endoprosthesis}

Simulations were conducted by using the ADINA program owned by the Institute of Mechanical Technologies at the Technical University of Czestochowa.

The geometrical model was based on real solutions of modular set by Aesculap [4].

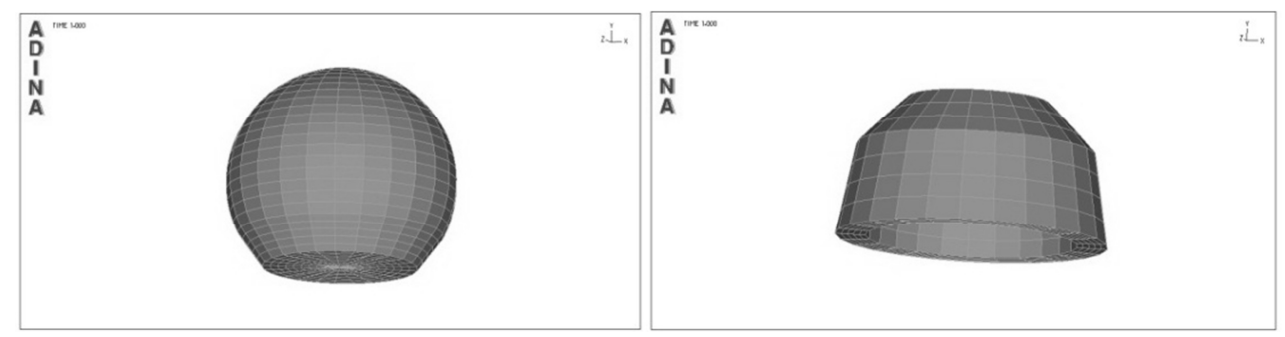

Fig. 3. Geometrical model of "head - cup" set of elaborated solution

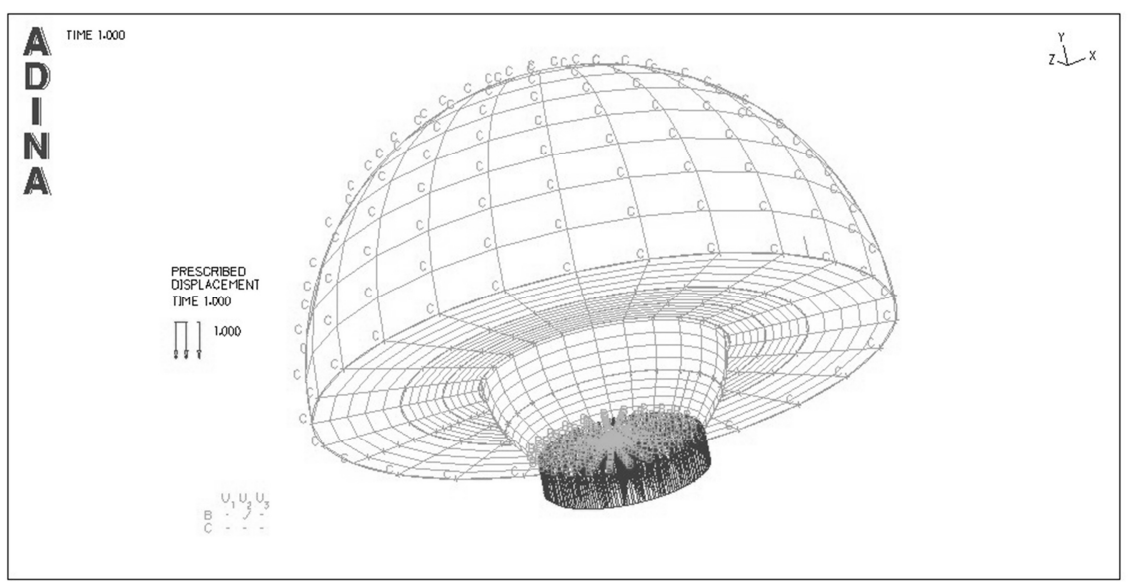

Fig. 4. Model of discreet elaborated solution 
Discreet model consists of 10000 cubic elements distributed on 10292 nodes. 8 node elements 3D Solid were used to build up the model.

Strength parameters of the materials and bone tissue used in analysis are presented in the Table 1.

Table 1

Mechanical features of biomaterials and bone tissue [6]

\begin{tabular}{|c|c|c|}
\hline Element of the model & Young's module $[\mathrm{MPa}]$ & Poisson's coefficient $v$ \\
\hline Core bone & $1.7 \times 10^{4}$ & 0.35 \\
\hline Alloy Ti6Al4V & $1.1 \times 10^{5}$ & 0.3 \\
\hline Ceramics $\mathrm{Al}_{2} \mathrm{O}_{3}$ & $3.8 \times 10^{5}$ & 0.22 \\
\hline
\end{tabular}

In the discreet model of "head - cup" both elements are ceramic. In the tested set the load refers to the load to which the head is subjected in the plain XY with strength 600 and $900 \mathrm{~N}$.

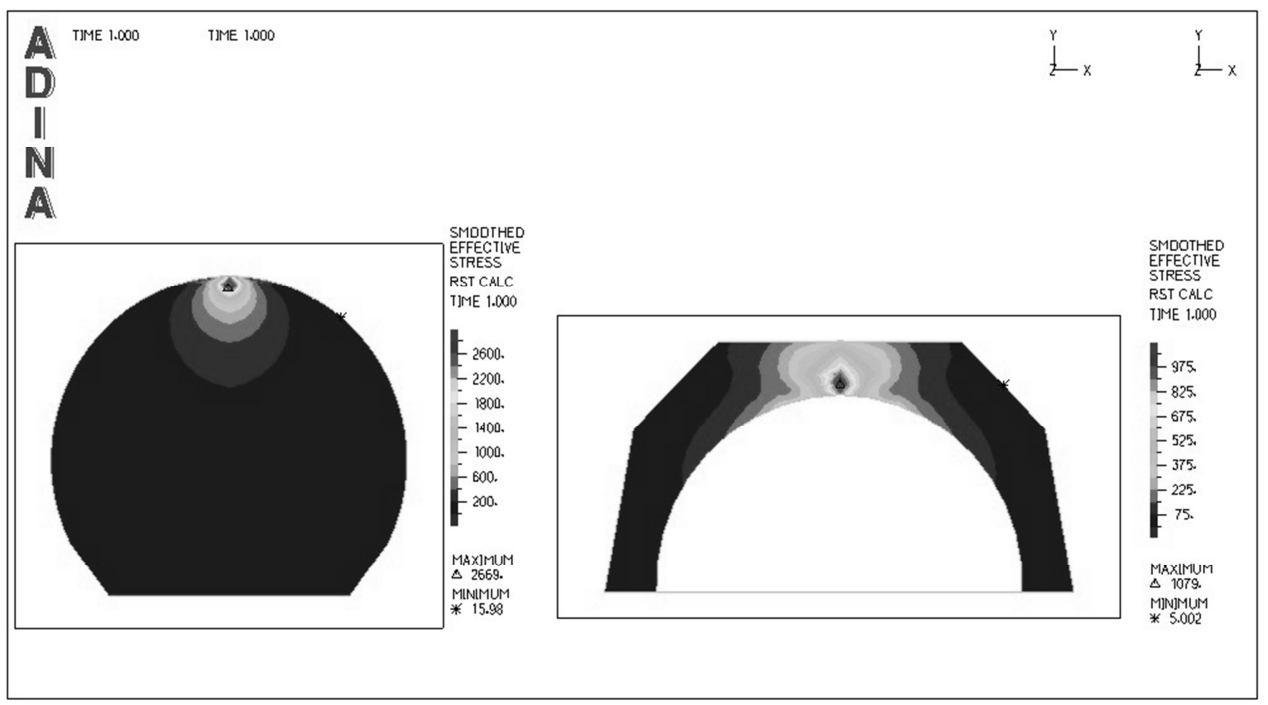

Fig. 5. Stress patterns $\sigma_{z r}[\mathrm{MPa}]$ in cross-section of each element of the analyzed system of ceramic head - ceramic cup, with the load $600 \mathrm{~N}$

The obtained results proved that due to the cooperating elements' parameters, the contact point occurs. It concentrates the stress which can reach in the surface area $2669 \mathrm{MPa}$ when the load is $600 \mathrm{~N}$, and $2900 \mathrm{MPa}$ when the load is $900 \mathrm{~N}$. The contact point between the cooperating surfaces transfers the stress onto the cups. 


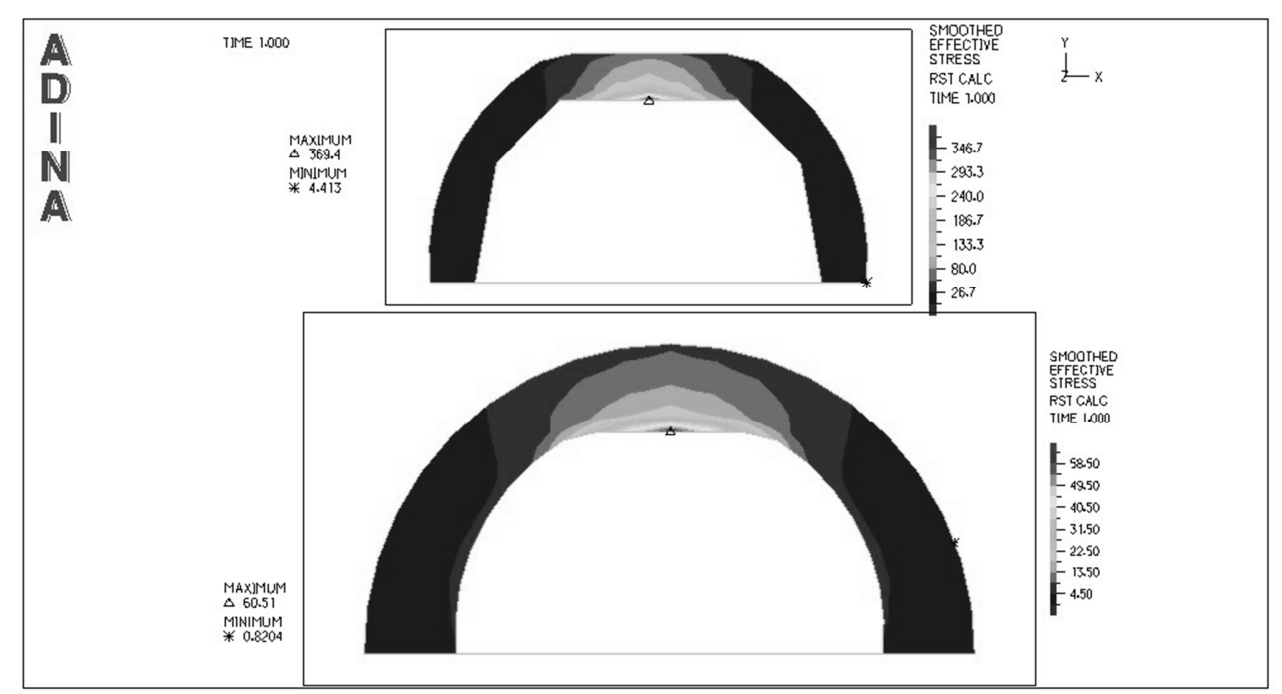

Fig. 6. Stress pattern $\sigma_{z r}[\mathrm{MPa}]$ in cross-section of casing of core bone in the analysed system, with the load $600 \mathrm{~N}$

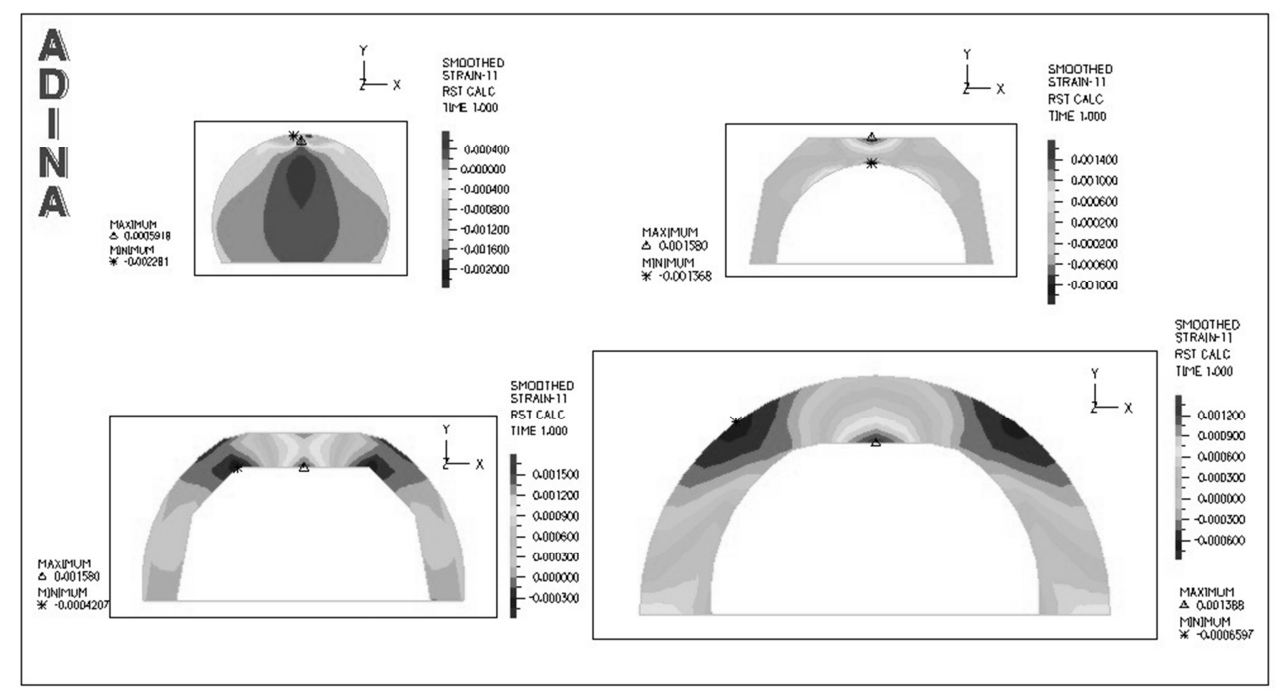

Fig. 7. Strain patterns in cross-section for each element of the analyzed system: ceramic head - ceramic cup with the load $600 \mathrm{~N}$

The strain distribution showed that biggest ones occur in the area where the cup is connected with the casing, and that the pelvis bone was deformed.

The obtained stress and strain distribution for the assigned materials prove that the ceramic elements in the analysed system will not be damaged. 


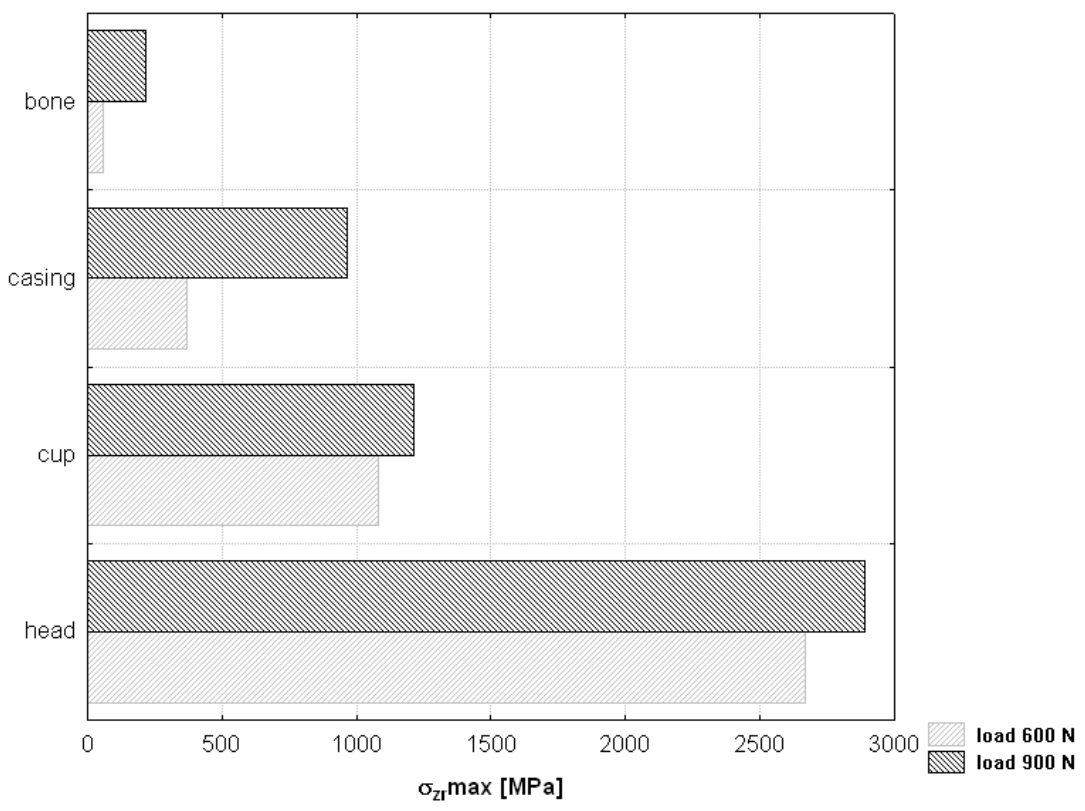

Fig. 8. Statement of the maximum values of stresses in the elements of the analysed system with the load 600 and $900 \mathrm{~N}$

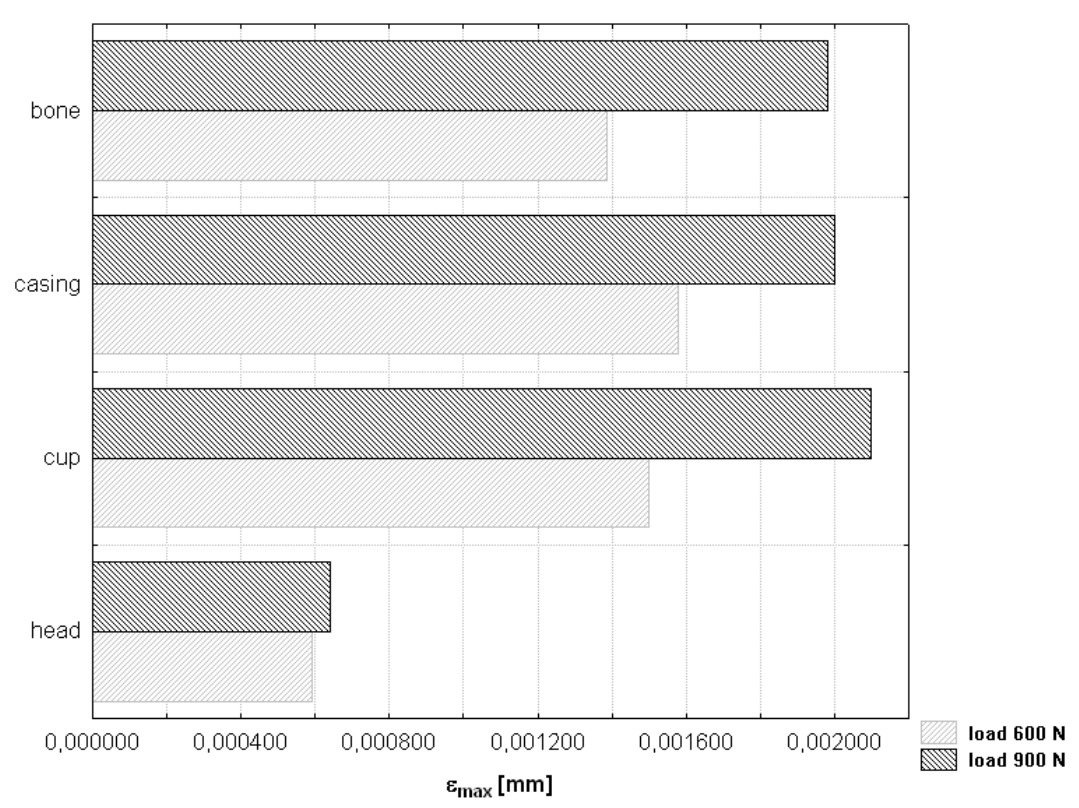

Fig. 9. Statements of the values of strain in the analysed system with the load 600 and $900 \mathrm{~N}$ 


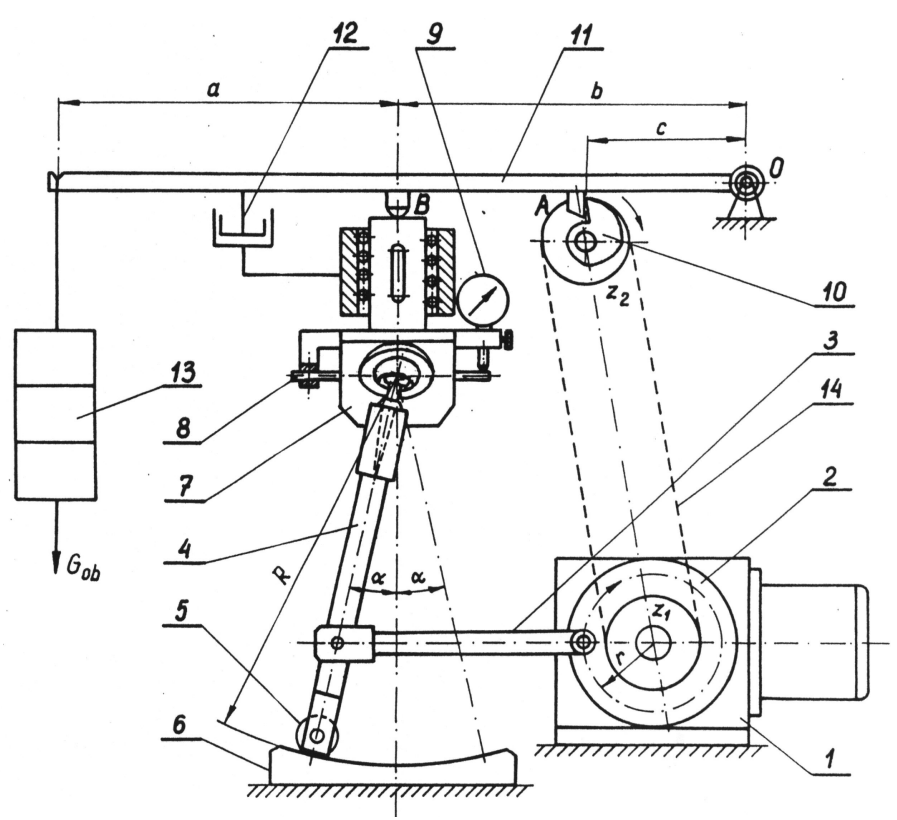

Fig. 10. Schematic diagram of the stand for testing durability of human hip joint endoprosthesis [7]

All the above results were positively confirmed in the empirical tests carried out on the hip joint simulator in the biotribology laboratory in the Institute of Mechanical Technologies. When the real set "ceramic head - ceramic cup" was subjected to load 600 and $900 \mathrm{~N}$ respectively, the values of friction coefficient grew significantly for that set run [8]. However, that did not cause any damage of the analysed ceramic elements.

\section{References}

[1] http://www.wmt.com

[2] Raabe J., Zastosowanie zginania trójpunktowego i emisji akustycznej do prognozowania wytrzymałości ceramiki konstrukcyjnej, Materiały Elektroniczne 11992, (77).

[3] Oczoś K., Kształtowanie ceramicznych materiałów technicznych, Oficyna Wydawnicza Politechniki Rzeszowskiej, Rzeszów 1996.

[4] The company brochure Aesculap no. 0-132.

[5] ADINA. Theory and Modeling Guide, Adina R\&D, INC, 1997.

[6] Będziński R., Biomechanika inżynierska, Oficyna Wydawnicza Politechniki Wrocławskiej, Wrocław 1997.

[7] Optymalizacja doboru materiałów i obróbki powierzchniowej niektórych endoprotez narządów ruchu człowieka w oparciu o badania tarciowo - zużyciowe, Praca zbiorowa pod red. M. Gierzyńskiej-Dolnej. Sprawozdanie z projektu badawczego Nr 7 T08C 03809, 1998.

[8] Gierzyńska-Dolna M., Biotribologia, Wydawnictwo Politechniki Częstochowskiej, Częstochowa 2002. 